\title{
A DESAPROPRIAÇÃO POR UTILIDADE PÚBLICA NO DIREITO BRASILEIRO E OS DIRETTIOS DE TERCEIROS
}

\author{
ODÍLIA FERREIRA DA LUZ OLIVEIRA (*)
}

I

Possivelmente, nenhum instituto jurídico sofreu em pouco tempo evolução mais radical do que a propriedade. Do conceito clássico como direito absoluto, ainda aceito no século XIX, chegou-se à propriedade encarada como função social e, assim, sujeita a diferentes limitações que atingem as condições de seu exercício e seu próprio conteúdo, com fundamento no interesse coletivo.

Foi ela entendida durante séculos como o direito de usar, fruir e dispor de uma coisa em caráter absoluto, exclusivo e perpétuo, isto é, sem limitações relativas ao conteúdo, à extensão e à duração dos poderes do proprietário.

Modernamente, não mais se pode aceitá-la nesses termos, como direito exercido única e exclusivamente em benefício de seu titular. Surge, portanto, nos ordenamentos jurídicos atuais, a propriedade como função socia I(art. 160, III, da Constituição do Brasil), que deve atender, também, ao interesse coletivo. Como tal, seu conteúdo e seu exercício são regulados não só por normas de Direito Privado, como também de Direito Público. Pode, então, ser conceituada como o direito de usar, gozar e dispor de uma coisa no interesse precípuo, mas não exclusivo, de seu titular, com as limitações legais ditadas por sua função social.

Acompanhando, em linhas gerais, a explanação de BENJAMIN VILLEGAS BASAVILBASO (1), torna-se clara a interferência do Direito Administrativo nesse campo até há algum tempo reservado ao Direito Civil.

(*) Professor Assistente do Departamento de Direito Público da Universidade Federal do Paraná.

(1) BENJAMIN VILLEGAS BASAVILBASO, Derecho Administrativo, 1956, vol. VI, p. 11 a 53 , passim. 
Em conseqüência da regulação da propriedade privada pelo Direito Público e pelo Direito Privado, deixaram de existir, obrigatoriamente, as três carazterísticas clássicas. Não é mais direito absoluto po:que está suje:ta a restrições estabelecidas pelas leis civis e administrativas, respectivamente, os direitos de vizinhança e as restrições (limitações) administrativas. As exclusividade cede antes o reconhecimento da ex stência de direitos reais sobre coisa a'heia, ao passo que a perpetuidade encontra obstáculo nas figuras da propriedade resolúvel, da propriedade revogável e da desapropriação.,

As limitações são impostas à propriedade privada pelo Direito Civil quando se visa à tutela de um interesse privado e pelo Direito Administrativo quando se busca resguardar 0 interesse público. A este respeito, é bastante explícito o Código Civil argentino, no ari. 2.611:

"As restrições impostas ao domínio privado somenie no interesse público são regidas pelo direito administrativo".

Interessam a este trabalho, de maneira particular, as limitações estabelecidas pelo Direito Administrativo, as quais serão brevemente mencionadas.

A) Restrições (ou limitações) administrałivas, que afastam o caráter absoluto da propriedade, são genéricas, constantes e atuais, configurando condições legais de seu exercício, o modo normal pelo qual se exerce.

B) Servidóes administrativas, que retiram da propriedade o caráter de exclulsividade, provocando o desmembramento dos poderes que the são inerentes. Constituem limitações particularizadas, pois incidem sobre bens determinados e existem em caráter potencial, ao contrário das restrições administrativas.

C) Desapropriação, que leva à extinção da propriedade privada, com prejuízo de sua perpetuidade, sendo potencial, a exemplo das servidões administrativas.

Por uma exigência lógica, antes que se trate de algum instituto jurídico, convém procurar conceituá-lo, o que nem sempre é tarefa isenta de dificu'dades. No que se refere à desapropriação, embora os vários conceitos encontrados possam diferir no aspecto formal, substancia!mente há uma idéia básica e comum: a da transferência coativa da propriedade individual, nos casos previstos em lei e mediante justa indenização com a finalidade de que a mesma propiredade passe a servir a um fim de interesse coletivo. 
Evidentemente, pode haver variações quanto ao objeto mediato ou imediato da desapropriação. Em alguns sistemas legais estrangeiros, só pode ela recair sobre imóveis ou direitos a eles relativos, com raras exceções, como ocorre na Itália (Lei n. ${ }^{\circ} 2.030$, de ...... 22/6/1948) e na França (Ordenança n..$^{\circ} 58.997$, de 23/10/1958).

No direito brasileiro, admite-se a expropriação não somente de bens corpóreos - hipótese mais comum - como também de bens incorpóreos (os direitos autorais são um exemplo). Ainda mais, o próprio objeto imediato não se restringe à propriedade, entendida como o direito real de conteúdo mais amplo (art. 524, do Código $\mathrm{Ci}$ vil), mas se estende a outros direitos, quais sejam, os de crédito e os direitos reais limitados.

Outra variação admitida pelo direito pátrio diz respeito à indenização: enquanto na desapropriação por utilidade pública ela será obrigatoriamente prévia, naquela regida pelo Decreto-lei $n .^{\circ} 554$, de 25-04-69, para fins de reforma agrária, é posterior à transferência da propriedade, o que, de certa forma, desvirtua o conceito clássico do instituto.

Este trabalho restringir-se-á aos direitos de terceiros na hipótese da desapropriação por utilidade pública de bens corpóreos, limitando-se basicamente ao direito brasileiro atual.

\section{III}

A Constituição Federal, no art. 153, § 22, não se refere apenas ao direito que tem o proprietário do bem expropriado de ser indenizado, mas, como esclarece SEABRA FAGUNDES,

"A palavra PROPRIEDADE, segundo o ensinamento, que se pode dizer unânime, dos nossos tratadistas, abrange QUAISQUER DIREITOS COM EXPRESSÃO ECONOOMICA..." (2)

Este comentário ao art. 141, § 16, da Constituição vigente à época ainda é válido, pois a garantia constitucional permanece.

O fundamento de tal indenização reside no fato de se estar frente a um sacrifício do interesse privado que não tem caráter genérico: pelo contrário, é individualizado, atingindo não a coletividade como um todo, mas pessoa certa e determinada. Assim, será ela indenizada pelo sacrifício de seus interesses, correspondendo essa indenização a uma repartição do encargo por toda a coletividade que, ao pagar impostos, contribui para a formação da receita pública.

(2) Miguel SEABRA FAGUNDES, Da Desapropriação no Direito Brasileiro, 1949, p. 414. 
O mesmo princípio, como já se viu, deve ser estendido a terceiros que, embora não sejam proprietários do bem desapropriado, são titulares de direitos sobre ele incidentes ou com ele relacionados. Não se adotando essa posição, os interesses de tais pessoas seriam injustamente sacrificados, uma vez que não é apenas o direito do proprietário do bem expropriado que se extingue, mas quaisquer outros direitos porventura existentes deixarão de incidir sobre ele.

Isso, porém, não significa necessariamente que os citados direitos de terceiros desaparecerão sumariamente do mundo jurídico, sem a devida compensação. Em qualquer hipótese, porém, quer o direito se extinga totalmente, quer deixe apenas de onerar o bem desapropriado, deve-se atender ao interesse efetivamente atingido pela expropriação.

Outro ponto que merece atenção é o que diz respeito à natureza das normas reguladoras deste aspecto específico da desapropriação. Embora os direitos do proprietário e de terceiros sejam regidos pelo Direito Privado no que respeita à sua formação, exercício e extinção, é o Direito Público - mais especificamente o Direito Administrativo - que regula o instituto da desapropriação em todos os seus aspectos. Assim, as regras de Direito Privado a esse respeito devem ser interpretadas e aplicadas em consonância com os princípios e normas de Direito Público.

\section{IV}

Em primeiro lugar, será tratada, genericamente, a situação dos titulares de direitos reais limitados que incidam sobre o bem desapropriado.

A noção de direito real corresponde à de um poder jurídico exercido direta e imediatamente sobre um bem, sendo oponível erga omnes. Partindo-se deste conceito, verifica-se que é bastante clara e evidente a necessidade de serem resguardados os interesses dos titulares de direitos desta espécie, constituídos sobre a coisa desapropriada, uma vez que estão ligados a ela de forma mais íntima que os direitos obrigacionais.

A questão está em saber de que maneira será concretizada essa proteção. Já se viu que o bem desapropriado transfere-se ao expropriante livre de quaisquer ônus ou direitos que sobre ele recaiam. Portanto, seria necessário que a própria lei assegurasse um meio de se resguardarem interesses de terceiros.

O Decreto n. ${ }^{\circ} 1.021$, de 26-8-1903 e seu regulamento (Decreto n. 4.956, de 9-9-1903) davam ao problema solução bastante seme- 
Ihante à consagrada pelo Decreto-lei n. ${ }^{\circ} 3.365$, de 21-6-1941. Estabelecia o primeiro deles, no art. $2 .^{\circ}, \S 8 .^{\circ}$ :

"As questões entre proprietários e locatários ou quaisquer terceiros não impedirão, em caso algum, o seguimento do processo de desapropriação. E, pois, em falta de acordo entre os interessados, o Governo depositará o preço das avaliações para que sobre ele os interessados exerçam seus direíros; e feito o depósito, o Governo entrará na posse do prédio, continuando o processo desembaraçadamente". (grifou-se).

Já o Decreto n. 4.956/1903 continha o seguinte preceito, no art. 11:

"A reivindicação, resolução e quaisquer outras ações reais não poderão sobrestar o pronunciamento da desapropriação, nem impedir o efeito da transferência da propriedade, livre e desembaraçada de todos os encargos judiciais e extrajudiciais; salvo aos reclamantes alegarem e disputarem seus direitos sobre o preço, que for consignado em depósito, como indenização, e nele ficarão subrogados todos os ônus, hipotecas e lides pendentes, quer a desapropriação se opere por sentença judicial, quer por convenção amigável". (grifou-se).

Por sua vez, o Decreto-lei n. ${ }^{\circ} 3.365 / 41$ dispõe, no art. 31:

"Ficam subrogados no preço quaisquer ônus ou direitos que recaiam sobre o bem expropriado."

Este último preceito não menciona expressamente sua aplicação quer à desapropriação amigável, quer à que se efetua mediante procedimento judicial, como fazia o Decreto n. ${ }^{\circ} 4.956 / 1903$. Surge, assim, a necessidade de interpretá-lo, para verificar seu alcance.

EURICO SODRÉ afirma que a mesma orientação foi mantida, nada havendo que faça supor a revogação do art. 11 do referido Decreto (3). Em favor da mesma tese, poder-se-ia, ainda, acrescentar a colocação do art. 31 nas disposições finais do Decreto-lei n. ${ }^{\circ}$ $3.365 / 41$, cujo texto não autoriza a distinção entre procedimento administrativo e procedimento judicial, para só aplicá-lo ao segundo; além do mais, a publicidade da desapropriação estaria assegurada com a publicação do decreto de utilidade pública em jornal oficial.

Outra corrente, porém, adota orientação diversa, ao afirmar

(3) EURICO SODRÉ, A Desapropriação por Utilidade Pública, 2.a ed., p. 145 a 148. 
que a subrogação de pleno direito, prevista no art. 31, só se aplica na hipótese de desapropriação mediante procedimento judicial, pois apenas neste existe publicidade suficiente para que terceiros interessados possam fazer valer seus direitos.

Realmente, a simples publicação do decreto de utilidade pública em jornal oficial não é suficiente, na prática, para levar ao conhecimento de eventuais titulares de direitos sobre o bem a intenção de desapropriá-lo. Se assim não fosse, por que se exigiria, no procedimento judicial, a providência constante do art. 34 do Decreto-lei n. ${ }^{\circ} 3.365 / 41$ (publicação de editais, par'a conhecimento de terceiros)? Além disso, a mera declaração de utilidade pública não significa que, a final, ocorrerá obrigatoriamente a desapropriação.

Em outros sistemas legais, como, por exemplo, o italiano e o francês, a desapropriação amigável está cercada de maiores precauções quanto à publicidade, o que autoriza a subrogação legal em qualquer hipótese. Nunca, porém, no direito brasileiro, cuja sistemática é diferente neste assunto, exigindo-se grande cautela por parte do expropriante, antes de efetuar o pagamento da indenização ao proprietário do bem.

O fato de se resguardarem expressamente os interesses dos terceiros titulares de direito reais sobre 0 bem não significa que a cada um deles corresponderá uma indenização distinta $\left({ }^{4}\right)$. $O$ texto dos arts. 26 e 31 do Decreto-lei n. ${ }^{\circ} 3.365 / 41$ afasta quaisquer dúvidas a respeito: a indenização será sempre única. $O$ que pode variar é a extensão desta: em alguns casos, corresponde apenas ao valor da propriedade; em outros, a este valor soma-se o do direito de terceiro. Tal assunto será tratado com maiores detalhes em outra parte deste trabalho.

Cumpre assinalar que há opiniões em contrário, como a do Professor MANOEL DE OLIVEIRA FRANCO SOBRINHO:

(4) Época houve, entretanto, em que o direito positivo brasileiro admitia expressamente a pluralidade de indenizações. $O$ Decreto n. ${ }^{\circ} 353$, de 12-7-1845, assim dispunha no art. 23: "Serão fixadas indenizaçōes distintas em favor das partes que as reclamarem sobre títulos diferentes. No caso de usufruto, porém, uma só indenização será fixada pelo Júri, em atenção ao valor total da propriedade, e o usufrutuário e o proprietário exercerão seus direitos sobre a quantia fixada. O usufrutuário, não sendo pai, ou mãe do proprietário, poderá ser obrigado a prestar fiança". Normas de mesmo alcance encontravam-se no Regulamento para a execução da Lei n.0 816, de 10.7-1855 (art. 12, al. 3.9), no Decreto n. $1.021 / 1903$ (art. $2 .^{\circ}, \S \S 7 .^{\circ}$ e $8 . .^{\circ}$ ) e no Decreto n. $0^{\circ} 4.956 / 1903$ (arts. 31 , §§ $1 .^{\circ}$ e $2 .^{\circ}, 33,34$ e 35 ). 
"A indlenização será uma só. A avaliação deverá ser feita como se a coisa fosse livre de ônus, que por acaso recaiam sobre ela e a tornem juridicamente onerosa ou intransmissível. Não interessa ao desapropriante que o preço da indenização seja ou não suficiente para cobrir - débito, que incidir sobre o valor da coisa em litígio". (5 - grifou-se).

Por outro lado, nem sempre se pode falar propriamente em subrogação do direito no preço, pois ela significa que aquele, embora extinguindo-se sobre $\circ$ bem, persistirá íntegro sobre o valor monetário do mesmo. Em certos hipóteses, que serão estudadas individualmente, o direito desaparece por inteiro do mundo jurídico; aí, não há subrogação, mas apenas indenização, em seu sentido próprio de compensação de um prejuízo.

\section{$\mathbf{v}$}

Já se viu que constitui princípio indiscutível a necessidade de ser atendido o interesse de todos os titulares de direitos sobre o bem ou com ele relacionados. A primeira vista. parece que 0 art. 31 do Decreto-lei n. ${ }^{\circ} 3.365 / 41$ resolveria a questão, sempre que se tratasse de desapropriacão efetivada mediante procedimento judicial. Entretanto, o problema não é tão simples, face ao disposto no art. 26:

"No valor da indenizacão, que será contemporâneo da avaliação, não se incluirão direitos de terceiros contra 0 expropriado." (grifou-se)

E evidente que não se pode estar frente a uma contradicão do legislador, tornando-se necessária uma interpretação dos dois artigos.

A melhor parece ser a de PONTES DE MIRANDA: 0 art. 26 aplica-se aos direitos obrigacionais e o 31, aos direitos reais (6).

O próprio texto de ambos os dispositivos autoriza esta interpretação, uma vez que 0 art. 26 refere-se a direitos de terceiros contra - expropriado e o art. 31, a ônus ou direitos que recaiam sobre o bem expropriado.

O Supremo Tribunal Federal, ao julgar o recurso extraordinário

(5) MANOEL DE OLIVEIRA FRANCO SOBRINHO, Desapropriação por Utilidade Pública, 1942, p. 115.

(6) PONTES DE MIRANDA, Tratado de Direito Privado, 3.a ed., tomo XIV, p. 180 a 181 . 
n. ${ }^{\circ}$ 51.817, em 1963, seguiu a mesma orientação, quando interpretou o alcance do citado art. $26\left(^{7}\right)$. Em certo trecho do voto do relator, Ministro Vilas-Boas, encontra-se o seguinte, com referência ao locatário:

"Os cálculos, que devem ser precisos, se referem ao jús proprietatis ou aos elementos em que se decompõe, e nunca aos efeitos das convenções a que, ad rem, esteja vinculado o titular do domínio."

Diante disso, como solucionar a questão dos titulares de direitos obrigacionais relacionados com o bem expropriado (locatários, comodatários, etc.), sobretudo levando-se em conta que tais direitos extinguem-se $\infty \mathrm{m}$ a desapropriação?

Para tanto, basta que se aplique a teoria do fato do príncipe, a qual envolve a responsabilidade civil do Estado por atos lícitos. Como bem esclarece Marcello Caetano, são pressupostos dessa forma de responsabilidade:

1) que haja sacrifício de um direito individual ao interesse público;

2) que o sacrifício - certo, atual e duradouro - não seja imposto à generalidade dos indivíduos, mas a pessoa certa e determinada;

3) que ele resulte de ato administrativo legal ou operação material lícita;

4) que o seu objeto seja um direito subjetivo ou uma coisa, em qualquer das hipóteses suscetível de apreciação pecuniária. $\left.{ }^{8}\right)$

Como $\circ$ art. 26 do Decreto-lei n. $3.365 / 41$ não permite que a indenização devida aos terceiros titulares de direitos obrigacionais seja incluída na indenização apurada no curso do processo, deverão tais terceiros obter o ressarcimento por meio de ação direta contra - expropriante; além disso, deverão provar não só o prejuízo e sua extensão, como ainda o fato de decorrer ele direta e imediatamente da desapropriação (nexo causa!). Essa exigência não é feita aos titulares de direitos reais, dada a própria natureza destes.

O que não se pode admitir, em princípio, é o expropriado respondendo pelos prejuízos, uma vez que a desapropriação, nas relações entre particulares, pode ser equiparada ao caso fortuito, o qual isenta o devedor de qualquer responsabilidade por danos eventualmente causados ao credor, a menos que se tenha ex.pressamente res-

(7) Revista de Direito Administrativo 73/168.

(8) MARCelo CAETANO, Manual de Direito Administrativo, 1.a ed. brasil., tomo II, p. $1.15,1$ a 1.153 . 
ponsabilizado por eles (Código Civil, art. 1.058). Na '́ltima hipótese - bastante rara - respeitando-se a autonomia da vontade individual, nenhuma responsabilidade caberá ao expropriante.

VI

Se, declarada a utilidade pública de um bem, para efeito de desapropriação, o seu proprietário entrar em acordo com o expropriante quanto ao preço oferecido, ter-se-á a chamada desapropriação amigável, que não exige a intervenção do Poder Judiciário, em regra.

O direito brasileiro não cerca esta forma de desapropriação de uma publicidade ampla, ao contrário de certos ordenamentos jurídicos estrangeiros, como o francês e o italiano (Ordenança n..$^{\circ}$ 58.997, de 23-10-58 e Lei $n .{ }^{\circ} 2.359$, de 25-6-1865, respectivamente).

A lei francesa, no art. 10, estabelece que

"Tendo em vista a fixação das indenizações, o expropriante publica e notifica aos proprietários e usufrutuários interessados quer o parecer de abertura da pesquisa, quer - ato declaratório da utilidade pública, o arrêté de cessibilité e a decisão judicial de desapropriação.

Nos oito dias seguintes, o proprietário e o usufrutuário estão obrigados a convocar e fazer conhecer ao expropriante os arrendatários, os titulares dos direitos de enfiteuse, de habitação ou de uso e os que podem reclamar servidões. Os demais interessados deverão fazer valer seus direitos pela publicidade coletiva prevista na primeira alínea do presente artigo e devem, no mesmo prazo de oito dias, fazer-se conhecer pelo expropriante, sem - que decairão de todos os direitos à indenização."

Já a lei italiana, nos arts. 53 e 54, também determina providências que, assegurando a publicidade dos atos que compõem o procedimento expropriatório, permitem aos terceiros interessados que façam valer seus direitos.

Não havendo no direito brasileiro, em regra, a ampla publicidade e não se aplicando, aqui, o art. 31 do Decreto-lei n. ${ }^{\circ} \ldots$ $3.365 / 41$, os terceiros ficariam desamparados, em princípio. quer seus direitos sejam de natureza real, quer sejam obrigacionais.

Constituindo louvável exceção, o Decreto-lei n. ${ }^{\circ} 512$, de ... 21/3/1969, ao cuidar do procedimento a ser seguido nas desapropirações amigáveis levadas a $\in$ feito pelo Departamento Nacional de Estradas de Rodagem - DNER - estabelece o seguinte, no art. 18: 
"Havendo concordância do expropriado com o valor do laudo, a quantia da avaliação será depositada, por sessenta dias, em conta bloqueada em estabelecimento bancário existente na Comarca da situação do bem ou na mais próxima, à disposição da autoridade judicial a que for requerido o depósito".

O $\S 1 .^{\circ}$ do mesmo artigo exige a publicação de editais, na Comarca da situação do bem e no local do domicílio do expropriado, se conhecido, dando-se o prazo de trinta dias para que terceiro interessado impugne a titularidade do bem ou se habilite por qualquer direito sobre o bem ou com ele relacionado. O juiz somente adjudicará a propriedade, por sentença, ao expropriante, para efeito de transcrição no Registro de Imóveis, se não houver impugnação relativa à propriedade, no prazo do edital ou inexistindo justo título ou, ainda, desde que os terceiros interessados a outro título se tenham devidamente habilitado. A importância depositada permanecerá bloqeuada, até que se decida a quem cabe levantá-la.

Tais exigências, semelhantes às previstas para o procedimento judicial no art. 34 e parágrafo único, do Decreto-lei n. ${ }^{\circ} 3.365 / 41$, deveriam ser estendidas a todas as hipóteses de desapropriação amigável. São bem mais simples que as existentes, por exemplo, no direito francês; apesar disso, são mais que suficientes para resguardar eventuais interesses de terceiros prejudicados e, principalmente, os do expropriante.

Entretanto, no atual estado de coisas, a não ser na hipótese mencionada, esses terceiros ficam aparentemente ao desabrigo de qualquer proteção. Na realidade, partindo-se do pressuposto de que a um sacrifício de direito individual que não tenha caráter genérico deve corresponder uma indenização, mesmo que ele se origine de ato lícito, o expropriente deverá agir com excepcâional cautela na desapropriação amigável.

Quais as providências a serem tomadas, na prática, pelo expropriante, a fim de não se deparar, no futuro, com problemas levantados por terceiros?

A existência de possíveis direitos reais limitados sobre bens imóveis poderá ser facilmente constatada junto ao Registro de Imóveis, pois a sua constituição só se dá com a inscrição neste último (art. 676 do Código Civil). Providência idêntica aplica-se ao penhor, com uma busca no mesmo Registro (penhor rural e o de máquinas e aparelhos utilizados na indústsria: art. 167, l, 4 e 15, da Lé n. ${ }^{\circ}$ 6.015, de 31/12/73) cu no Registro de Títulos e Documentos (pe- 
nhor comum e o de animais não compreendido nas disposições do art. 10 da Lei n. ${ }^{\circ}$ 492/37: art. 127, II e IV, da mesma Lei).

Quanto a outros direitos reais, que podem recair sobre bens móveis (usufruto e uso), a única medida realmente segura seria estender-se à desapropriação amigável a regra do art. 38 do Decreto-lei n. ${ }^{\circ} 3.365 / 41$, que indubitavelmente só se aplica à efetuada mediante procedimento judicial, pois se refere expressamente a réu:

"O réu responderá perante terceiros, e por ação própria, pela omissão ou sonegação de quaisquer informações que possam interessar à marcha do processo ou ao recebimento da indenização".

Issi, porém, exige modificação do direito vigente, a exemplo do que sucede com a questão da publicidade Portanto, o expropriante, atualmente, só se pode resguardar por meio de investigação direta, a qual nem sempre é segura.

No que respeita aos direitos obrigacionais, como o seu valor, em qualquer hipótese, não integra a indenização, devem seus titulares procurar 0 ressarcimento mediante ação direta contra o expropriante; assim, não é imprescindível qualquer iniciativa por parte deste último, em princípio.

Os direitos reais, por envolverem um poder jurídico exercido direta e imediatamente sobre a coisa, não se extinguem automatica. mente, em se tratando de desapropriação amigável. Daí, su:ge a necessidade de especial cautela por parte do expropriante, visando à verificação da existência dos mesmos e às providências relacionadas com o pagamento da indenização.

E oportuno citar, em defesa desta tese, certos trechos de um parecer de FRANCISCO CAMPOS:

"Quanto à desapropriação, em si mesma, o proprietário é obrigado a sofrê-la, mesmo contra a sua vontade. Não existe, pois, desapropriação amigável ou por acordo; o acordo só poderá versar sobre o quantum da indenização." (grifou-se) "Sendo certo, como é, portanto, que o desapropriante não sucede ao desapropriado no domínio sobre a coisa, mas o adquire originariamente, ou de maneira incondicional, ou sem qualquer limitação, ainda que o desapropriado não seja o proprietário real, mas apenas o proprietário aparente, segue-se que a uma simples escritura de cessão da propriedade não pode ter a eficácia 
da desapropriação. Pela escritura de cessão da propriedade, o desapropriante só poderá adquirir os direitos do desapropriado sobre a coisa, ou apenas sucede a esse nos seus direitos em relação ao bem que deveria ser objeto do processo de desapropriação". (gritou-se). $\left({ }^{9}\right)$

Assim sendo, no caso, o expropriante recebe o bem com todos os ônus reais que sobre ele recaírem; e enquanto os titulares destes direitos não obtiverem o ressarcimento, a desapropriação não se terá consumado.

Outro tanto não se pode dizer dos direitos obrigacionais, dada a sua peculiar natureza e que se convertem em simples direito a indenização de possíveis prejuízos. Nem mesmo o contrato de locação devidamente registrado e do qual conste a cláusula de sua vigência na hipótese de alienação (art. 1197 do Código Civil) tem tratamento diverso: em primeiro lugar, porque não cria direito real para o locatário; além disso, a desapropriação, mesmo amigável, não pode ser equiparada a uma simples alienação, no sentido a esta conferido pelo citado dispositivo. A respeito do contrato de locação, é pacífica a jurisprudência a respeito de sua extinção pela expropriação (v., por exemplo, RDA 18-73, 43-220 e 88-159).

Já se afirmou que, no direito brasileiro atual, é princípio indiscutível o da indenização única, na desapropriação, o que não significa, entretanto, que apenas o titular do direito de propriedade será ressarcido: também os terceiros com direitos sobre o bem expropriado ou com ele relacionados são protegidos pelas normas e princípios jurídicos que regulam a matéria.

O Decreto-lei n. ${ }^{\circ} 3.365 / 41$, em primeiro lugar, manda citar o proprietário do bem, o administrador da sociedade proprietária ou - administrador do condomínio (quando se tratar do autêntico condomínio e não da chamada propriedade horizontal); pertencendo ao espólio, será citado o inventariante e, na sua ausência, o cônjuge, herdeiro ou legatário detentor da herança (art. 16).

Em momento algum, determina-se a citação de terceiros interessados, ao contrário do Decreto n. ${ }^{\circ} 4.956 / 1903$, que no art. 19 dispunha 0 seguinte:

"Os proprietários e interessados que residirem no foro da situação do imóvel serão citados pessoalmente, e se residirem fora, ou estiverem ausentes, serão notificados por editos, com o prazo de 30 dias..."

(9) Revista de Direito Administrativo 24/310 e 313 . 
Nada impede, porém. que os titulares de direitos reais limitados, os quais podem fazer valer seus direitos sobre a indenização, compareçam ao processo na qualidade de assistentes do réu. Essa possibilidade não se abre aos titulares de direitos obrigacionais, em virtude do que dispõe o art. 26 do mesmo Decreto-lei.

Por outro lado, o expropriado deve levar ao conhecimento do juiz a existência apenas desses terceiros titulares de direitos rea's limitados sobre a coisa expropriada, sob pena de responder pessoalmente perante eles, com total liberação do expropriante (art. 3); não há exigência relativa aos titulares de direitos meramente obrigacionais, pelo motivo já exposto.

Seria conveniente, porém, que se voltasse à sistemática do antigo Decreto n. ${ }^{\circ} 4.956 / 1903$, com a citação obrigatória dos titulares de direitos reais limitados, após a manifestação do expropriado prevista no art. 38 do Decreto-lei n. ${ }^{\circ} 3.365 / 41$.

Serão apreciados agora, dentro do contexto da desapropriação, os vários direitos reais limitados que podem onerar o bem expropriado.

ENFITEUSE - Sendo a enfiteu-se o direito real limitado que mais amplos poderes confere a seu titular - poderes de usar, fruir e dispor da coisa com caráter de perpetuidade - nada impede que a ação seja proposta contra o enfiteuta (titular do domínio útil), embora o senhorio direto (titular do domínio eminente) seja o verdadeiro proprietário do bem.

No que diz respeito à parcela da indenização que caberá a cada um deles, é ponto pacífico que o enfiteuta receberá o valor do domínio pleno, menos vinte foros e um laudêmio, parcela esta que será destinada ao senhorio direto. É a orientação unânime dos tribunais, consagrando $o$ que já dispunha $o$ art. 33 do Decreto n. ${ }^{\circ} \ldots$ $4.956 / 1903$.

Tratando-se de aforamento de imóvel pertencente ao próprio expropriante, é evidente que só se pode falar em indenização do domínio útil, pois é apenas este que está sendo desapropriado:

"Desapropriação - Imóvel foreiro - Cá'culo da indenização. Sendo o imóvel edificado em terreno foreiro, de cujo domínio direto é titular o expropriante, da indenização deve ser deduzido o valor correspondente a vinte foros e um laudêmio." $\left({ }^{0}\right)$

(10) STF - RE n.॰ 71.723, de 1972 - Revista de Direito Administrativo 111/254. 
SERVIDÃO - Aqui, não há propriamente subrogação do direito na importância paga a título de indenização. O conteúdo da servidão é a utilidade que o imóvel serviente desapropriado traz ao dominante; assim, por sua própria natureza, este direito real não pode ser exercido sobre uma importância em dinheiro e, com a expropriação, extingue-se não apenas em relação ao imóvel sobre o qual recaía, mas desaparece do mundo jurídico de forma integral.

Neste caso, portanto, ao valor do imóvel deverá ser acrescentado - do prejuízo sofrido pelo titular da servidão, para efeito do cálculo da indenização. Sobre a importância que lhe couber, terá o proprietário do imóvel dominante direito de preferência. Acrescente-se, ainda, que a existência da servidão poderá ser levada em conta no momento de se proceder à avaliação do imóvel expropriado, como fator de desvalorização.

O direito italiano, que nisto diverge do nosso, autoriza a conservação da servidão, desde que não haja dano ou grave incômodo ao imóvel dominante ou ao serviente (art. 45 da Lei n. ${ }^{\circ} 2.359 / 1865$ ).

O Código Civil brasileiro (art. 708), dispensa expressamente a formalidade do cancelamento deste direito real limitado, quando houver desapropriação do prédio serviente.

USUFRUTO - A subrogação real tem aqui plena aplicação, o que é confirmado não somente pelo art. 738 do Código Civil, como pelo fato de que este direito é passível de modificação quanto ao seu objeto (no caso, modificação qualitativa). Ocorrendo a subrogação e, em conseqüência, extinguindo-se o direito apenas sobre - bem expropriado, procede-se, quanto ao cálculo da indenização, de forma diversa da utilizada na hipótese de servidão: não se soma ao valor do bem a importância correspondente ao ressarcimento do prejuízo, pois prejuízo não há.

Entende PONTES DE MIRANDA que a ocorrência da subrogação real impede a transformação do direito em causa no chamado usufruto impróprio, isto é, aquele que recai sobre coisas fungíveis ou consumíveis, do qual o usufruto de dinheiro é exemplo típico $\left({ }^{11}\right)$.

USO e HABITAÇÃO - Face ao que dispõem os arts. 745 e 748 do Código Civil, determinando a aplicação a estes direitos, no que couber, das normas que regem o usufruto, haverá a subrogação real e a indenização será calculada levando-se em conta apenas o valor do bem expropriado.

(11) PONTES DE MIRANDA, ob. cit., tomo XIX, p. 271 e 137. 
RENDA CONSTITUÍDA SOBRE IMÓVEL - O Código Civil, no art. 749, estabelece que

"No caso de desapropriação, por necessidade ou utilidade publica, de prédio sujeito a constituição de renda (arts. 1.424 a 1.431), aplicar-se-á em constituir outra 0 preço do imóvel obrigado..."

A este respeito, esclarece PONTES DE MIRANDA:

"Recebida a indenização, sobre ela recai o gravame em subrogação real. Mas essa indenização tem de ser aplicada de modo que o novo bem gravado dê para as prestações devidas". ${ }^{(12)}$

Por aí, vê-se que a indenização paga pelo expropriante será obrigatoriamente aplicada de forma a permitir que o ônus real passe a recair sobre outro imóvel, capaz de proporcionar a renda devida. Isso pode significar a aquisição de novo imóvel, com a importância paga a título de indenização.

Havendo, apenas, substituição do bem sobre o qual recai o ônus, o direito não desaparece do mundo jurídico, da mesma forma que $\circ$ usufruto e a indenização paga abrange somente $\circ$ valor do imóvel expropriado.

DIREITO REAL. DO PROMITENTE COMPRADOR DE IMÓVEIS - A promessa de compra e venda - pré contrato ou contrato preliminar de imóveis loteados, desde que devidamente aveibada no Registro de imóveis (art. 5..$^{\circ}$ do Decreto-lei n. ${ }^{\circ}$ 58, de 10-13-37), cria para o promitente comprador, cumpridas as exigências legais, um direito real de prioridade para a aquisição da propiredade da coisa, como assinala ALTINO PORTUGAL SOARES PEREIRA. $\left({ }^{3}\right) 0$ mesmo acontece em relação à promessa de compra e venda de imóveis não loteados, sem cláusula de arrependimento e inscrita no mesmo registro (art. 22 do citado Decreto-lei, com a redação dada pela Lei n. ${ }^{\circ}$ 649, de 11-3-49).

O conteúdo deste direito é amplo, composto de vários poderes que se exercem sobre o bem. Assim é que o promitente comprador tem a posse, o uso e a fruição do imóvel. Além disso, tal direito transmite-se mortis causa ou por ato inter vivos (cessão). Como assinala ORLANDO GOMES, o promitente comprador é proprietário potencial do bem $\left({ }^{14}\right)$

(12) PONTES DE MIRANDA, ob. e loc. cit., p. 418.

(13) Altino PORTUGal SOAReS PEREIRA, A Promessa de Compra e Venda de Imóveis no Direito Brasileiro, 1957, p. 90.

(14) ORLANDO GOMES, Direitos Reais, 1. ${ }^{a}$ ed., p. 440. 
Desapropriado o imóvel a que se referem esses pré-contratos, é evidente que $o$ direito real limitado extingue-se totalmente e não apenas em relação ao bem expropriado. Por sua própria natureza, não poderá subsistir sobre uma importância em dinheiro.

À primeira vista, poder-se-ia admitir que, desapropriado o imóvel prometido à venda, a indenização deveria ser paga ao promitente vendedor, que é o proprietário, cabendo ao promitente comprador, tão somente, a devolução das importâncias já pagas, a serem descontadas do total da indenização e acrescidas de juros de mora.

Esta solução, aceitável em fases de estabilidade monetária, é flagrantemente iníqua em épocas inflacionárias. Portanto, a questão exige uma apreciação cautelosa que, sem ignorar os princípios jurídicos aplicáveis, propicie sua adequação aos fatos, conduzindo a soluções forçosamente diversas, conforme o preço estipulado já tenha sido integral ou parcialmente pago e, neste último caso, distinguindo entre estar ou não o devedor em mora.

Na hipótese de pagamento integral do preço, a indenização deverá ser paga ao promitente comprador, pois a transferência da propriedade dependeria, somente, da outorga da escritura definitiva, substituível pela adjudicação compulsória (art. 346 do Decreto-lei n. ${ }^{\circ}$ 1.608, de 18-9-39, mantido em vigor pelo art. 1.218, 1, do Código de Processo Civil vigente), caso não se tivesse consumado, ainda, a desapropriação, uma vez que foi cumprida integralmente a obrigação nascida do contrato preliminar. Não constitui obstácu'o a esta solução - fato de que a propriedade do imóvel não chegou a ser transferida. A indenização, na desapropriação, visa a substituir o bem expropriado no patrimônio de seu titular; mas, desfalcado, no caso, está o patrimôn'o do promitente comprador e não o do vendedor, que já recebeu o preço estipu'ado, em sua totalidade.

Se este preço foi parcialmente pago e o titular do direito real não está em mora, a indenização fixada será paga ao promitente vendedor, deduzindo-se, em favor daquele, uma parcela que esteja, para o total da indenização, na mesma proporção que as importâncias pagas estão para o total do preço estipulado, ou seja, metade, um terço, etc.. Exemplificando: do preço estabelecido pelas partes em $\mathrm{Cr} \$ 100.000,00$, já foram pagos $\mathrm{Cr} \$ 10.000,00$. Fixada a indenização em Cr\$ 500.000,00, ○ promitente comprador receberá Cr $\$ 50.000,00$.

A impontualidade no pagíamento das prestações acarreta, em princípio, a resolução da promessa de compra e venda. Quando se tratar de imóveis loteados, a mora é ex persona. A lei impõe a inti- 
mação do promitente comprador para que pague as prestações vencidas, as que vencerem até a data do pagamento, os juros convencionados e as custas da intimação, no prazo de trinta dias contados deste (art. 14 do Decreto-lei n. ${ }^{\circ}$ 58/37). Decorrido o prazo sem o pagamento, opera-se a resolução. No caso de imóveis não loteados, dividiu-se a doutrina no que toca à incidência do dispositivo citado, face à norma contida no art. 22 do mesmo Decreto-lei, com a redação dada pela Lei $n .^{\circ} 649 / 49$. Filiando-se à corrente que nega a extensão do preceito, DARCY BESSONE entende que a mora e a resolução da promessa de compra e venda de imóveis não loteados regem-se pelas regras do direito comum, sobretudo as dos arts. 955, 959, 960, 963 e 1.092, do Código Civil $\left({ }^{15}\right)$

Desapropriado o imóvel e ocorrendo impontualidade no pagamento das prestações, o direito do promitente comprador de participar da indenização dependerá, evidentemente, de o contrato preliminar não se ter resolvido, nas condições acima referidas. óo caso de imóveis loteados, há uma peculiaridade a ser observada: se ainda não se configurou a mora, nos termos do art. 14 do Decreto-lei $n .^{\circ}$ $58 / 37$, será conveniente que a indenização permaneça depositada até o exaurimento do prazo concedido pela lei para a purgação da mora, aplicando-se, analogicamente, a regra do art. 34 do Decreto-lei n. ${ }^{\circ} 3.365 / 41$, incidente no caso de dúvida quanto à propriedade do bem expropriado.

$\mathrm{Na}$ hipótese, quase acadêmica pela sua excepcionalidade, de o valor da indenização ser inferior ao preço estipulado na promessa de compra e venda, não haverá responsabilidade do expropriante, face ao princípio maior de que a indenização fixada judicialmente corresponde ao real valor do imóvel desapropriado, não se podendo, assim, cogitar de prejuízo suscetível de reparação pelo Poder Público. Se a desapropriação for amigável, aplicar-se-ão os princípios anteriormente expostos (ítem VI).

DIRE:TOS REAIS DE GARANTIA - Levando-se em conta o que dispõe o Código Civil a respeito destes direitos reais, em norma que não conflita com as que regem a desapropriação, verifica-se que o penhor, a hipoteca e a anticrese, uma vez expropriado o bem dado em garantia, podem extinguir-se integralmente.

Nas disposições gerais a respeito, o Código assim regula a matéria, no art. 762, V:

"A dívida considera-se vencida:

(15) DARCY BESSONE, Da Compra e Venda, 1960, p. 217 a 218. No mesmo sentido: ALTINO PORTUGAL SOARES PEREIRA, ob. cit., p. 130 a 133. 
V - Se se desapropriar a coisa dada em garantia, depositando-se a parte do preço, que for necessária para o pagamento integral do credor".

Enquanto a indenização fixada estiver depositada, não se pode cogitar de pagamento; portanto, permanece o direito de preferência do credor sobre ela. Mas, uma vez levantada a importância correspondente ao crédito, o débito extingue-se e, com ele, o direito real de garantia, que é acessório.

Evidentemente, a importância deste crédito não se soma ao valor do bem expropriado, para efeito de cálculo da indenização: uma vez que garantia da dívida era o próprio valor do bem. pouco importa que este seja inferior ao daquela; ainda mais que, em regra, existe a aceitação pelo credor daquele determinado bem como ga"antia. Ocorrendo a hipótese de a indenização ser inferior ao crédito garantido, pode-se aplicar, por analogia, 0 art. 767 do Código Civil:

"Quando, excutido o penhor, ou executada a hipoteca, - produto não bastar para o pagamento da dívida e despesas judiciais, continuará o devedor obrigado pessoalmente pelo restante".

Por isso, é importante - embora não imprescindível - a intervenção do credor titular de garantia real no processo de desapropriação na qualidade de assistente do expropriado, pois poderá melhor defender seus direitos.

Situação peculiar é a do credor anticrético, cujo direito se resume em receber os frutos de um imóveis, esteja este em mãos de quem quer que seja, até que seja integralmente satisfeito seu crédito. Talvez por recair a garantia apenas sobre os frutos do bem e não sobre o seu valor total, estabelece a lei civil que não terá ele preferência sobre a indenização depositada pelo expropriante (art. 808, § 2. ${ }^{\circ}$. Isso, de certa forma, envolve uma injustiça; mas dada a regra contida no art. 31 do Decreto-lei n. ${ }^{\circ} 3.365 / 41$, assegura-se tal preferência, mesmo a este credor $\left({ }^{16}\right)$.

Por outro lado, dispôs-se que

"Nos casos dos n. ${ }^{\circ} \mathrm{S}$ IV e V, só se vencerá a hipoteca antes do prazo estipulado, se os sinistro, ou a desapropriação recair sobre o objeto dado em garantia, e esta não abranger outros; subsistindo, no caso contrário, a

(16) MIGUEL SEABRA FAGUNDES, ob. cit., p. 430. 
dívida reduzida, com a respectiva garantia sobre os demais bens não desapropriados, danificados, ou destruídos". (Código Civil, art. 762, § $2 .{ }^{9}$ ).

Comentando este dispositivo, SEABRA FAGUNDES entende que "Se se tratar de hipoteca, que recaia sobre outros bens, além do expropriado, a sub-rogação no preço se dá proporcionalmente ao valor do bem desapropriado em face do total da dívida". $\left({ }^{17}\right)$

Admite-se, assim, a divisibilidade da hipoteca, sendo vários os bens hipotecados e não ocorrendo a desapropriação de todos: o credor será pago proporcionalmente e o crédito remanescente continuará garantido pelo restante dos bens.

Tratando-se de desapropriação parcial de um imóvel hipotecado, sem que haja direito de extensão, será possível admitir-se o mesmo procedimento? Parece que sim, tendo-se em vista não só que a indivisibilidade não é da essência dos direitos reais de garantia, podendo ser afastada até mesmo por convenção, como também que $\circ$ artigo acima referido admitiu a divisibilidade.

Antes de se passar à questão dos direitos obrigacionais, é necessária uma referência à solução a ser dada quando ocorrer a imissão provisória na posse do bem, prevista no art. 15 do Decreto-lei n. ${ }^{\circ} 3.365 / 41$. Não se poderá permitir que o expropriado levante parte da importância depositada sem que tenham sido notificados todos os titulares de direitos reais limitados incidentes sobre o bem, a fim de que façam valer seus direitos das diversas maneiras já apontadas. Seria conveniente, mesmo, que o próprio direito positivo previsse e regulasse expressamente tal situação.

\section{VIII}

A desapropriação, em qualquer hipótese, extingue sempre os

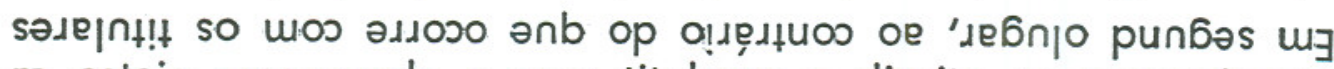
ra esteja assegurado a seus titulares o direito ao ressarcimento de prejuízos causados direta e imediatamente pela expropriação.

O caso mais típico é o da locação, por ser o mais comum. O Código Civil e as leis extravagantes que regulam a matéria - estas mais fortemente do que aquele - buscam proteger especialmente o locatário de imóveis, partindo do pressuposto de ser ele econômicamente mais fraco, frente ao proprietário.

(17) MIGUEL SEABRA FAGUNDES, ob. cit., p. 431. 
Assim é que as sucessivas Leis do Inquilinato procuraram dificultar ao máximo a ação de despejo, tendência esta mitigada por leis mais recentes, porém retomada atualmente, com algumas limitações. Já o Código Civil contém dispositivos mais amenos, embora esteja longe de deixar o locatário ao desamparo total.

A questão que poderia emergir seria a da aplicação dessas normas na hipótese de desapropriação do bem. Já ficou assente, porém, que as regras e princípios do Direito Privado, neste assunto, só terão incidência naquilo em que não conflitarem com o interesse público, predominante sobre o privado. Portanto, é evidente a inoponibilidade ao Poder Público de regras como a do art. 1.197 do Código Civil ou das contidas em leis extravagantes e que limitam a possibilidade de retomada do bem. Neste sentido, é pacífica a jurisprudência; a título de ilustração, veja-se o acórdão proferido pelo Tribunal de Alçada de São Paulo, no mandado de segurança n. ${ }^{\circ} 67.259$, de 1964:

"Desapropriação - Locação. A desapropriação resolve o contrato de locação". (18)

Até a simples imissão provisória na posse do bem, determinada pela urgência da desapropriação, acarreta a resolução do contrato de locação; se mesmo o proprietário do bem perde a posse, com muito maior razão perdê-la-á o locatário. E não há como admitir-se locação sem posse da coisa.

Restará, então, ao titular do direito obrigacional nascido do contrato de locação a possibilidade de obter o ressarcimento pelos prejuízos eventualmente sofridos.

Cabe, aqui, repetir certas afirmações feitas anteriormente: em primeiro lugar, a indenização não poderá ser pleiteada na própria ação de desapropriação, face ao que preceitua o art. 26 do Decreto-lei n. ${ }^{\circ}$ 3.365/41 (vejam-se, a respeito: RDA 44/288 e 73/168); para isso, deverá o locatário socorrer-se de ação direta contra o expropriante.

Em segundo lugar, os contrário do que ocorre com os titulares de direitos reais, deverá o titular de direito obrigacional provar a existência e a extensão do prejuízo, bem como o nexo de causalidade entre ele e a desapropriação.

Tratamento semelhante ao do locatário terão os demais titulares

(18) Revista de Direito Administrativo 88/159. No mesmo sentido: RDA 18/73, $43 / 220$ e $87 / 212$. 
de direitos obrigacionais (por exemplo, o comodatário) que tenham a posse da coisa expropriada.

Finalmente, merecem especial atenção os direitos de vizinhança, que são limitações legais ao exercício da propriedade, derivadas da proximidade entre prédios e estabelecidas pelo direito a fim de se evitarem conflitos resultantes dessa proximidade.

De início, devem ser fixados dois pontos básicos: o conceito exato de vizinhança e o fundamento das restrições.

Como assinala ORLANDO GOMES,

"A vizinhança é um fato que, em Direito, possui significado mais lato do que na linguagem comum. Consideram-se prédios vizinhos aqueles que podem sofrer repercussões de atos propagados de prédios próximos ou que com estes possam ter vínculos jurídicos". $\left({ }^{19}\right)$

Por outro lado, embora tais normas procurem conciliar imediata e diretamente os interesses dos proprietários, não são ditadas com fundamento exclusivo no interesse privado, mas também, embora mediatamente, no interesse coletivo, que exige constante harmonia entre os indivíduos, evitando que o uso nocivo da propriedade seja causa de conflitos.

E controvertida a natureza jurídica de tais direitos: para alguns, constituem servidões legais, enquanto para outros, são limitações à propriedade e se enquadram entre as chamadas obrigações ob rem ou propter rem, figuras intermediárias entre os direitos reais e os obrigacionais. Esta última tese é a adotada por nosso direito positivo.

Convém distinguir os direitos de vizinhança das limitações administrativas. Ambos têm em comum a característica de constituírem condições legais do direito de propriedade, de se inserirem em seu conteúdo normal, isto é, de serem o modo normal de seu exercício. Em conseqüência, são limitações genéricas e indispensáveis ao exercício da propriedade, fundamentando-se no princípio da solidariedade social $\left({ }^{20}\right)$

A distinção reside no fato de estarem sujeitos a regimes jurídicos diversos, em função da categoria de interesses a que dizem respeito de maneira imediata. Os direitos de vizinhança, por visarem à proteção do interesse privado, são regidos pelo Direito Privado, mais especificamente pelo Direito Civil, ao passo que as limitações

(19) ORLANDO GOMES, ob. cit., p. 261.

(20) B. V. BASAVILBASO, ob. e loc. cit., p. 41 a 42. 
administrativas, objetivando a tutela imediata do interesse público, regulam-se pelo Direito Administrativo, ramo do Direito Público. Além disso, as limitações administrativas, dada a sua generalidade, são sempre gratuítas, ou seja, não conferem direito a indenização, ao passo que, em nosso ordenamento jurídico, os direitos de vizinhança podem ser onerosos ou gratuítos, apesar de serem também restrições genéricas.

A importância dessa distinção reflete-se na competência legislativa. Uma vez que compete exclusivamente à União legislar sobre Direito Civil (art. 8. $.^{\circ}, \mathrm{XVII}, \mathrm{b}$, da Constituição Federal), somente ela poderá regular os direitos de vizinhança. Dada, porém, a competência concorrente da União, dos Estados e dos Municípios para a criação de normas jurídicas em matéria administrativa, estas três pessoas políticas poderão legislar sobre limitações administrativas, embora se faça sentir, na prática, a preponderância da legislação municipal.

O Código Civil trata dos direitos de vizinhança nos arts. 554 a 588, com os seguintes temas: árvores limítrofes, passagem forçada, águas, limites entre prédios, direito de construir e direito de tapagem.

Alguns destes direitos, que criam ônus excepcionais, são necessária ou eventualmente onerosos, isto é, têm seu exercício condicionado ao pagamento de uma indenização sempre devida (arts. 560, 567 e 579 do Código Civil) ou somente devida se for causado algum prejuízo (arts. 564, 567, parágrafo único, 587 e 588, § $4 .^{\circ}$ ). Outros direitos de vizinhança são gratuitos, pois correspondem a encargos ordinários da propriedade $\left({ }^{20}\right)$.

Uma vez desapropriado determinado imóvel, poderão os vizinhos continuar a exercer estes direitos em relação a ele?

No que respeita aos direitos de vizinhança gratuitos, cujo exercício nenhum prejuízo ou ônus acarreta, em princípio pode-se responder afirmativamente, sobretudo na parte relacionada com o direito de construir, que sofre limitações impostas também pelo Direito Administrativo. Em casos concretos, porém, se excepcionalmente houver prejuízo para o interesse público, a solução será diversa.

Quanto aos direitos necessária ou eventualmente onerosos, cujo exercício acarreta um dano atual ou potencial, impõe-se resposta negativa: em regra geral, o interesse público seria sacrificado de

(21) F.C. DE SAN TIAGO DANTAS, O Conflito de Vizinhança e sua Composição, ,2. ${ }^{a}$ ed., p. 253, 264 e 265. 
forma tal, que nem mesmo a indenização paga afastaria as conseqüências danosas. Basta que se imagine, a título de exemplo, o proprietário de imóvel contíguo ao desapropriado e no qual se construiu um hospital público ou uma delegacia de polícia, nele penetrando, mediante simples aviso prévio, a fim de promover obras de reparação ou limpeza em seu próprio prédio. O mais seguro, aqui, será admitir-se, com fundamento na supremacia do interesse público sobre o privado, a extinção desses direitos.

Sobretudo a passagem forçada, por sua natureza, deve extinguir-se como direito em virtude da expropriação. Neste caso, como em todos os outros nos quais o antigo titular do direito sofra graves prejuízos, aplicar-se-á o art. 37 do Decreto-lei n. ${ }^{\circ} 3.365 / 41$ :

"Aquele cujo bem for prejudicado extraordinariamente em sua destinação econômica pela desapropriação de áreas contíguas terá direito a reclamar perdas e danos do expropriante".

Indiscutivelmente, isso deverá ser feito emação direta e nunca na ação de desapropriação.

\section{IX}

No curso deste trabalho, criticou-se a legislação vigente, no que respeita quer à desapropriação amigável, quer à efetivada mediante procedimento judicial. Tais críticas dão margem às seguintes sugestões que, evidentemente, só se podem concretizar por via legislativa:

No que tange à desapropriação amigável:

1) Extensão a todas as hipóteses de desapropriação por utilidade pública das medidas preconizadas pelo art. 18 e $\S 1 .^{\circ}$, do Decreto-lei n. ${ }^{\circ}$ 512/69, já referido. Adotadas tais precauções, o expropriante libertar-se-ia dos ônus e problemas que, no regime atual, surgem como decorrência da falta de publicidade que cerca a desapropriação efetivada mediante acordo.

2) Como complemento dessa medida, poder-se-ia adotar norma semelhante à contida no art. 38 do próprio Decreto-lei n. ${ }^{\circ}$... $3.365 / 41$, o qual exige do expropriado que dê conhecimento da existência de terceiros com direito sobre a coisa, responsabilizarıdo-o pessoalmente perante estes pela sonegação das informações.

Em relação à desapropriação judicial: 
3) Exigência da citação dos terceiros com direitos reais limitados sobre o bem, mediante a prévia manifestação do expropriado prevista no art. 38 do Decreto-lei n. ${ }^{\circ} 3.365 / 41$.

4) Exigência expressa da notificação dos titulares de direitos reais limitados incidentes sobre o bem, antes que se permita ao expropriado levantar parte da importância depositada, quando houver a imissão provisória na posse. 